\title{
Leadership and Management Strategies That Promote the Implementation of Consumer-Centred Care in Residential Aged Care Facility
}

\author{
Mohanaa Naidu \\ Griffith University, Queensland, Australia \\ Email: mona7178@gmail.com
}

How to cite this paper: Naidu, M. (2019) Leadership and Management Strategies That Promote the Implementation of Consumer-Centred Care in Residential Aged Care Facility. Journal of Biosciences and Medicines, 7, 73-101.

https://doi.org/10.4236/jbm.2019.76006

Received: March 29, 2019

Accepted: June 14, 2019

Published: June 17, 2019

Copyright () 2019 by author(s) and Scientific Research Publishing Inc. This work is licensed under the Creative Commons Attribution International License (CC BY 4.0).

http://creativecommons.org/licenses/by/4.0/

(c) (i) Open Access

\begin{abstract}
Enhancing leadership and management in the aged care sector is likely to be achieved through adopting cultural changes that are aimed at promoting a healthy working environment in which employees have job satisfaction and are motivated to commit their efforts towards achieving the organizational goals. A conducive working environment offers support, inspiration, and harmonious social relationships among the workers in the aged care homes. Both management and leadership play a role in enhancing a healthy working condition obligatory for implementing new care initiatives, effective strategies and practices that should be appropriately articulated. The current research study aims at examining effective strategies and practices that enhance management and leadership in the aged care sector with the aim of ensuring that all care initiatives are successfully implemented. The research question for the study is focused on the leadership and management strategies used to promote the implementation of consumer-centered care in residential aged care facility. Analysis was aimed at understanding the importance of management and leadership in promoting the implementation of various initiatives surrounding new care models; in this case, the consumer-centered care model in the aged care facilities across Australia and other parts of the world. One major theme emerged from the analysis, which was transforming the organizational culture that was promoted through changing the organizational systems, embracing the "yes culture", and changing the individuals" work habits. The "yes culture" means that all individuals are dedicated to succeeding in making excellent decisions autonomously. The study identified that managers and leaders shifted their emphasis from compliance with laws and regulations to create a conducive work environment that empowers workers to support any new initiatives undertaken. The strategy was successful, according to the findings.
\end{abstract}




\section{Keywords}

Empowerment, Organization, Culture, Changes, Support

\section{Introduction}

The rapidly ageing population that has led to the transformation of healthcare services is one of the most fundamental concerns across the world. Although the government of many countries has introduced subsidies and reforms to support aged care services provided to the elderly, it is an undeniable fact that the residential aged care sector is experiencing workforce challenges arising from the increasing demands [1]. This has led to undesirable outcomes in the productivity and quality of care rendered by healthcare service providers. Hence it is important to initiate reforms in the aged care facilities that aim at improving the quality of healthcare services as well as providing holistic, cost-effective and efficient care.

The elderly residing in residential care areas ought to be given quality care in which their needs are adequately addressed. As the world population is aging, the aged care providers are not required to depend on the traditional ways of offering care services since the expectations among the population have shifted in recent years. It is projected that the older population aged between 60 and 70 years will require consumer-centered care in the residential care facilities provided for them in the future [2]. Thus, the healthcare service providers undertake effective strategies to adapt to the new initiative which addresses the needs of the aging population effectively.

In Singapore, the health ministry is focusing on the expansion of healthcare services and managing the growing aging population by building new acute hospitals, polyclinics, community hospitals, palliative care centers and nursing homes to provide optimal care for the elderly [3]. These initiatives would create job opportunities for many healthcare workers. However, healthcare workers prefer to be employed in acute care settings rather than long-term care settings and nursing homes [4]. As employees' job satisfaction, recruitment and retention were the main concerns in the residential aged care facilities. It is crucial to address the issue. According to Pol-Grevelink, Jukema \& Smits (2012) [5], healthcare workers are attracted to aged care facilities when they are given opportunities for career advancement, personal development and empowerment. The workforce retention and employees' commitment are achieved with effective leadership and management skills that motivate employees and foster them to adapt to the organizational culture [6] [7]. This would, in turn, enable the organization to achieve the organizational goals and outcomes successfully.

This paper aims to review journal articles with the consultation of staff in management level to gather suggestions and recommendations in assuming best strategies in management and leadership practices that promote the implemen- 
tation of new initiatives such as the consumer-centered care. The paper will include strategies that focus on leadership and managerial qualities that promote "yes culture", empowerment and commitment among employees as well as approaches for an organization to embrace change and reforms effectively. The paper will further explore and provide appropriate recommendations to establish strategies to promote effective leadership and management in the aged care sector.

\subsection{Background}

The demand for aged care services across the world is escalating significantly with the increasing number of individuals who are aged 85 years or more [8]. The impact of the growing demand for aged care services will be felt by the year 2030 when most of the baby boomers will be 85 years old [9]. The baby boomer generation is constituted of various demographics, making it difficult for the aged care service providers to offer services using the similar care models provided for older individuals and for those who are from the $\mathrm{X}$ Generation [8] [10].

Nurses assume various roles in both public and private aged care homes including government standard auditors as well as research managers. These roles offered the investigators an opportunity to understand the overall management and leadership styles of nurses in various global aged care homes [11] [12]. The nurses vary in the way they operate and manage an institution, and this is based on the expectations of the organization. The owners of the aged care homes can either limit nursing care, or offer the nurses with a chance to promote quality care [11] [13] [14]. The aged care facilities managers continuously struggle to address both the needs of the aged care homes and the needs of the elderly as well as the provision of a supportive and secure work environment for the organizational staff. The organizational culture and support offered by the managers and leaders impacts on the nurse managers' innovativeness and flexibility to implement new care models such as the consumer-centered care and person-centered care models [15] [16] [17]. Person-centered care is a care approach that delivers holistic and individualized care in which patients are empowered to make their own health decisions [18]. However, consumer-centered care focuses on health and illness of the patient as well as their family by enhancing confidence, creating awareness and providing support and reassurance [18].

Management and leadership development in the residential aged care sector has long been neglected in Australia. The recent reforms in the aged care sector aim to reduce the cost of age care delivery, implementation of technology initiatives and improve staff retention and job satisfaction. These reforms are difficult to be implemented without effective management and leadership, more so in this era when consumer-centered care is being embraced [3] [4]. Most aged care organizations have nurse managers who are responsible for numerous care facilities and employ a deputy in each care facility to oversee the administration processes [19]. The larger care organizations operate numerous aged care 
homes, which means that each nurse manager is in a pool of other nurses, independently managing care homes. The current project is significant because it promotes one's understanding regarding nurse managers' scope of responsibility in managing and making decisions to implement consumer-centered care.

\subsection{Question}

The research question designed to explore the area of the study states: What leadership and management strategies promote the implementation of consumer-centered care in residential aged care facilities across the world? The research question aims to explore and analyze effective strategies and recommendations that promote new care initiatives such as the consumer centred care in the aged care sector and identify the most appropriate leadership and management skills that would ensure the successful implementation. The rationale to select the review across the world is to determine the similarities and differences in leadership and management skills within the healthcare sector and analyze the success rate of specific leadership skills and the implementation of consumer-centered care in a larger scale.

The research question was explored through three other sub-questions to ensure that the investigator had a full understanding of the topic of study. The questions include:

Q1. What are the effects of implementing consumer-centered care in residential aged care facilities?

Q2. What are the essential characteristics associated with fostering effective clinical leadership and management to promote the implementation of new care programs such as the consumer-centered care in the residential aged care facilities?

Q3. What are the best strategies for establishing a sustainable workforce leadership that encompasses effective management across the aged care homes?

The research questions were formulated to have a better understanding of the focus on consumer-centered care that benefits residents in the aged care facility and the approach to successfully implement such care initiatives with the adoption of appropriate leadership styles and management skills. The questions were answered after a thorough, systematic review of the existing literature to determine the effects of consumer-centered care and the importance of having effective management and leadership in organizations to promote the process of implementing new care initiatives in the aged care facilities. The analysis was based on the objectives and the overall aim of the study to identify emerging themes that were relevant from the synthesis of the sources.

\subsection{Objectives}

The main objective of the current study was to provide effective strategies and recommendations to enhance management and leadership in the aged care sector to ensure all innovative projects at care facilities are successfully implemented. 
The study accomplished the following objectives to meet the aims by 9th October 2017:

- to analyze the need for consumer-centered care offered to the elderly living in the aged care facilities across the world;

- to determine strategies and practices encompassing the management and leadership in relation to the implementation of new care programs such as consumer-centered care;

- to determine whether the strategies and practices embraced by the management and leadership of the aged care facilities ensure successful implementation of change;

- to distinguish the importance of staff empowerment in decisions associated with the adoption and successful implementation of new care programs in the aged care facilities;

- to identify the approaches used by employees in the aged care facilities that are supported in decision-making, developing, and sustaining new skills associated with the new care programs; and

- to analyze the data that can be generalized for all aged care homes across Australia and the world after the implementation of innovative programs.

The study explored approaches that the managers and leaders undertake to enhance reforms aiming at implementing new care programs across the care facilities as well as aimed at modifying service delivery approaches on the workforce. With few nurse managers available in the aged care sector, the data collected through conducting a survey will be insufficient in determining the reforms and new aged care initiatives employed before and after implementation of new programs. Hence, the current study was conducted through a systematic review of the content of previous literature through the internet or/and the university library.

\section{Methods}

\section{Introduction}

This section presents the research methodology employed by the investigator to accomplish data collection, analysis, and use. The methodology selected guided the researcher in accomplishing the research aim and objectives [20] [21] [22] [23]. Bell (2014) [24] mentioned that the methodology is supposed to integrate well with the intended area of study. Hence the literature search for the current study focused on effective strategies, practices and recommendations to enhance management and leadership in the aged care sector to ensure that all care initiatives are successfully implemented.

The present study used a systematic literature review with the aim of exploring heterogeneity of sources to identify strategies that enhance management and leadership to make recommendations to aged care service providers. Usually, systematic literature reviews are conducted to gain knowledge on a topic and supported by high-quality evidence [25] [26] [27]. However, the current review 
is meant to offer an opportunity to establish excellent recommendations for action by the management and leadership of aged care facilities. A synthesis of the existing evidence was carried out and combined with views of professionals in the field of consultation [26].

\section{Search Terms and Engines}

Management and leadership related terms including "leadership", "management", "leaders", "managers", "organizational structure", "organizational culture and climate", "organizational behaviour", "organizational empowerment", or "organizational change" were combined with health-related terms including "aged care facilities", "residential aged care", "nursing homes", and "long-term care". Both black and grey literature was searched through electronic databases such as PubMed, Medline, and Cochrane, nursing leadership journals from the university library, and Google search engine.

\section{Selection of Study Materials}

The selection of study materials was made through inclusion and exclusion criteria. All materials exploring effective management and leadership in healthcare, with more focus on consumer-centered care settings constituting both theoretical and conceptual frameworks, organizational development, organizational culture, influencing factors, leadership development, efficient management models, policy guidelines, clinical management, and employee issues were included in the study. The articles were excluded if they featured health management, clinical management, care models, or service delivery in which the focus was clinical outcomes related to person-centered care management. All materials that were published before 2012, not written in English and dissertations were also excluded from the study.

The identified materials were excluded if they featured health management, clinical management, care models, or service delivery in which the focus was clinical outcomes related to person-centered care management. Figure 1 represents the PRISMA flow chart indicating the selection of the literature materials. Initial research produced 5441 results. After removal of duplicate sources, 4417 records remained. After following the exclusion criteria described above, only 767 records were obtained.

Based on the research questions, only systematic literature reviews were included. A total of 158 articles were chosen for an in-depth evaluation and summary of articles that featured clinical management and employee issues. $30 \mathrm{ar}-$ ticles that were not dissertations were included in the final report. The appropriateness, as well as relevance of the articles to be included or excluded, were verified in the review process. The quality of evidence was verified against the guidelines of the National Institute for Health and Clinical Excellence (NICE) [28]. An inclusive approach was utilized to test the diversity of the literature and was demonstrated to be successful in assessing the management and leadership challenges among workers.

\section{Consultations}

Purposeful sampling technique was used to identify a reference group, and 


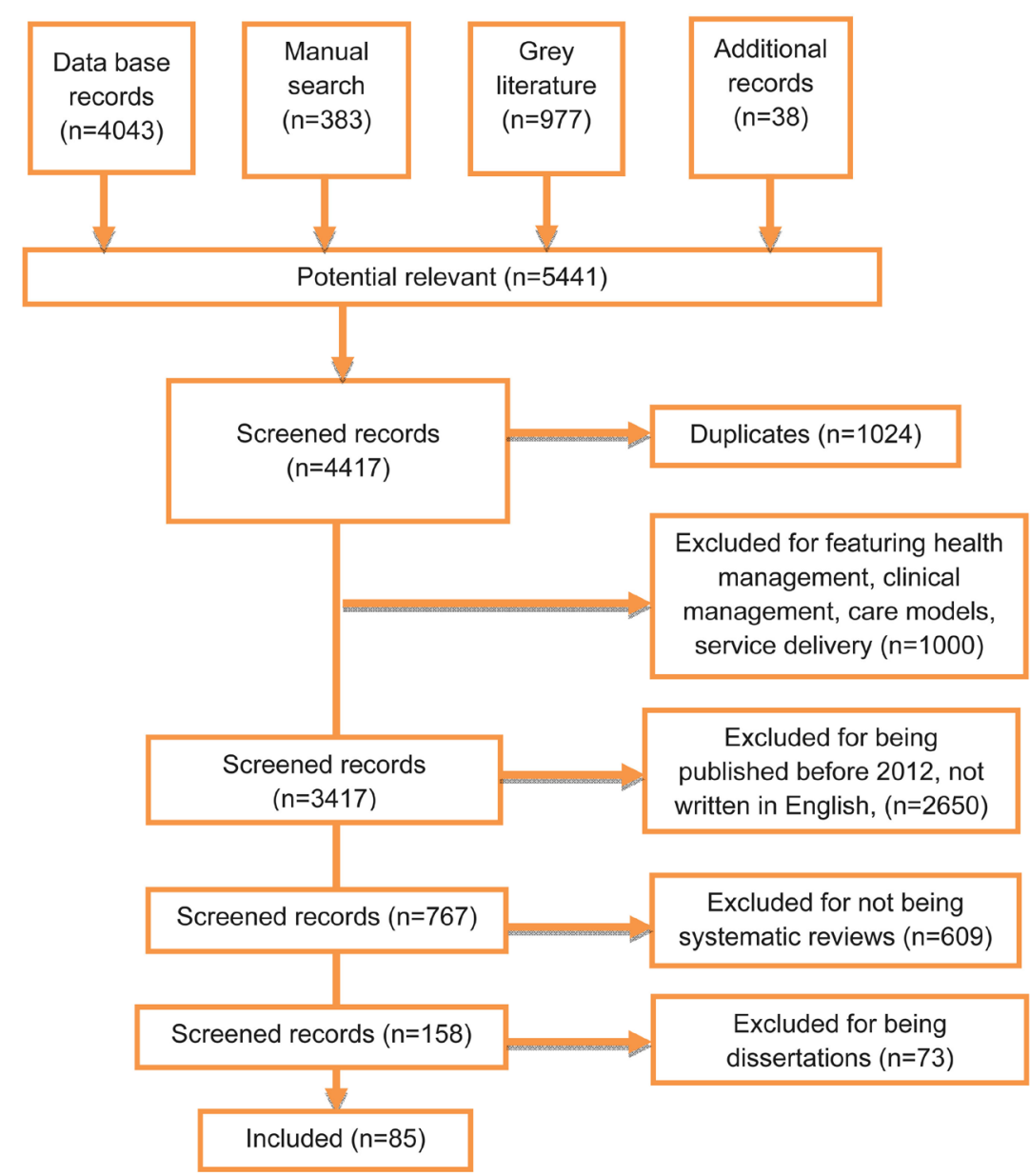

Figure 1. PRISMA flow Chart.

international professionals and care managers from whom consultation was sought, were identified [29]. The reference group included representatives from governmental and non-governmental aged care organizations from Australia and Singapore. These representatives were identified from LinkedIn profiles which shows their many years of experience in the aged care facilities. The advisors offered professional advice regarding the methods and conduct of the literature review and development of the results through emails and meetings. In Singapore, face-to-face interactions were held with the experts, constituting of senior researchers and nurse managers promoting leadership and management development. They also provided suggestions about some of the references that were to be included in the review process and key findings from the review. The main recommendations from the initial report were confirmed to be valid in relation to the existing literature and relevant to global contexts. In addition, the managers from the aged care facilities were invited to a meeting to verify the validity of the research findings and recommendations and to give further suggestions.

\section{Data Analysis}

Data analysis and synthesis were guided by the three research sub-questions and the articles that were reviewed to gather information for the literature re- 
view. The analysis revealed vital attributes that foster effective clinical leadership and management to endorse the execution of new care programs and establish a sustainable workforce in the residential aged care facilities.

\section{Analysis of Study Findings}

This section presents the results of the study from the secondary data sources. The initial search of the literature indicated that most of the materials were acute care oriented and overseas-based articles from the UK and US, with a few originating from Australia. The analysis provides a summary of the results about the research questions. The results showed that for successful implementation of new initiatives such as consumer-centered care, organizational culture that supports and empowers workers is required [30] [31] [32] [33] [34]. Dwyer (2011) debated that the management and leadership of the residential aged services ought to refine their operations and systems to implement the initiatives successfully.

\section{Limitations of the Study}

Theory development about aged care management and leadership research is limited, causing researchers to source appropriate models from health leadership and management discourse. There were limited resources reviewed as many search materials were published before 2012 and the articles reviewed for the current study was limited to less than five years of publication in order to analyze the latest findings. The reviewed articles in this paper failed to address the success of new care initiatives after the implementation process since it requires an individual to conduct an empirical study within the research environment. According to Jeon et al. (2015) [13], this lack of an empirical study makes it impossible to measure the effectiveness of the strategies employed by managers and leaders in implementing a given project. However, the study included more studies on the performance of managers and leaders that were aimed at diminishing failures. The project also intended to generalize the research findings to understand the impact of management and leadership on the success of global care home projects. However, it was a challenging task to generalize on the data collected since the aged care facilities differ in size [35]. Thus, more sources from different countries that have information related to the similarities and differences in leadership and management skills and analysis on consumer-centered care across healthcare settings were included.

\section{Literature Review}

\section{Introduction}

The literature review aims to explore the need and impact of consumer-centered care in the care of elderly in the residential aged care facility. With the implementation of consumer-centered care, the elderly in the aged care sector is expected to receive quality and holistic care with the care extended to their family. The strategies undertaken for the successful implementation of consumer-centred care requires effective leadership and management skills that 
create a positive organizational culture for employee's empowerment and commitment towards the organization's goal in order to embrace change and reforms. This review elaborates on the definition of consumer-centered care, the process of implementation, requirements to sustain and the optimal organizational culture in adapting consumer-centered care in the aged care facilities. In addition, the review focuses on employees' empowerment and commitment that enhance job satisfaction and the leadership and management skills that would support successful implementation of reforms.

\section{Consumer-centered Care}

Consumer-centered care is a service delivery model that was purposely designed to offer flexibility and autonomy to consumers [36] [37] [38] [39] [40]. The consumer-centered care was initially piloted across Commonwealth-funded aged care facilities in the fiscal year 2010-2011. The model was rolled out in Australia, the UK, and the US with the aim of providing freedom and flexibility, offering support to those seeking relevant information, promoting collaboration and better quality care, and enhancing wellness and transparency in service delivery across aged care facilities [41] [42] [43]. Consumer-centered care is vital in the current aged care delivery model, and it, therefore, requires optimistic staff and a healthy working environment. This would encourage staff to be motivated and committed to their duties and implement all initiatives associated with the system.

\section{Implementation of Consumer-centered Care in Aged Care Facilities}

According to Carmeli, Tishler, and Edmondson (2012), to successfully implement cultural reform models [44] including consumer-centered care, it is mandatory to be committed in providing excellent leadership and steady management with solid teamwork and effective communication strategies and by embracing investment in staff training about the expected cultural reforms. There is a consensus in the global literature that consumer-centered care is among the recommended models that will enhance care among the aging population [43] [44] [45] [46]. However, the literature from the UK shows that for effective implementation of the consumer-centered care model, aged care facilities ought to take into consideration the uniqueness of all members in the facility including residents and their families, employees, managers, and volunteers [47] [48] [49]. Thus, the successful implementation of the model greatly depends on a collaborative approach with effective management skills.

The commitment upheld by management will foster a supportive organizational culture known as a caring culture [50]. Furthermore, this new organizational culture attracts innovative strategies and practices to offer support during the implementation of various reform models [48] [49]. Van der Voet (2014) mentioned that the implementation of any reforms should occur at both individual and organizational levels. This would enable the organization to gain cooperation and build rapport with both the employees and consumers.

\section{A Consumer-Centered Care Facility}

The literature on attaining organizational standards also highlighted the im- 
portance of promoting cultural changes in implementing initiatives. Chenoweth et al. (2014) [51] claimed that a care organization should have systems that will ensure it functions normally but effectively with the formulated standards. According to Carayon et al. (2014), [51] organizations ought to monitor systems to maintain the formulated standards, therefore continuing staff training, constructive feedback systems, timely delivery of information, participatory decision-making, management schemes that promote quality care, and better working conditions. Fetherstonhaugh et al. (2016) suggested that aged care providers are supposed to adopt reform models that consider the larger organizational context to avoid failure. For instance, to successfully operate aged care facilities and services in the US, nurse managers promote an organizational culture that effectively supports new care models [21] [48] [52] [53]. Through offering care home staff, the skills, funds, and systems to support them in doing their duties, management and leadership become culture carriers defining the work ethics in an institution [52]. Through promoting cultural changes in an organization, the staff will be motivated and in the process, support the management in implementing programs.

\section{Organizational Culture and Consumer-centered Care}

It is obligatory for aged care providers to establish a shared organizational culture across all levels of institutions to ensure consumer-centered care is rendered appropriately. Some of the global organizations describe their service delivery as being consumer-centered, without promoting the required organizational cultural change [8] [54]. Organizational culture refers to the values, beliefs, and staff perceptions regarding the work setting and about their managers [55]. Organizational culture has been noted to influence the behaviour of persons and groups operating in an organization. Despite organizational culture and climate being viewed as different from each other, the research on health care facilities showed that organizational culture and organizational climate are closely related [14]. Hence, any change in an organizational culture would result in altering the organizational climate.

After conducting a survey of global business units constituting larger aged care homes in Australia, it is recommended that a conceptual framework which gives more information on the organizational climate in the Australian healthcare is developed [56]. The framework constituted of seven elements including people, property, purpose, peace, progress, participation, and passion for linking management systems with objectives and results of the organization. The elements were assigned specific components as follows: people (teamwork and motivation), property (resources of the organization), purpose (organizational goals), peace (staff wellness), progress (consumer outcomes), participation (organizational structures and systems), and passion (staff commitment). Alfes et al. (2013) [57] linked purpose, participation, and property to progress and passion, meaning the management and leadership initiatives that yield good results promote staff commitment. According to the model, purpose, participation, and property are associated with people, meaning that effective initiatives encourage teamwork 
and inspire individuals.

Nurse managers in Australia, the UK, the US, and France have been noted as establishing an organizational culture in which people's values and beliefs were respected, staff issues were addressed amicably, and the residents' information was readily available to the nursing staff [50] [58]. Information required by the nursing staff includes residents' health records, preferred care lifestyles, aged care policy, training materials, and timely information regarding any expected organizational changes [59] [60] [61] [62]. By offering the nursing staff this information, the management will be empowering them as they deliver their duty, thereby promoting staff satisfaction and flexibility in delivering consumer-centered care.

Successful strategies and practices for execution of consumer-centered care are based on the socio-emotional and participative management approach together with staff training on expected changes [63] [64] [65]. Supportive organizational culture is associated with successful implementation of reform models, in this case, consumer-centered care model. There is a need to identify strategies and practices to establish, implement, and assess care models, including the consumer-centered care model in aged care facilities. The fundamental feature to be considered when adopting consumer-centered care is the ability of managers and leaders to enhance knowledge and skills among the workers.

\section{Worker's Commitment and Empowerment}

Leadership attributes play a crucial role in modifying employees' performance and embracing change in an organization. Papastavrou et al. (2015) [66] acknowledged that consumer-centered care could only enhance care among the ageing and dementia populations if the management and leadership offer a supportive organizational culture. The culture is supposed to give the workers independence and a learning atmosphere to make excellent decisions to deliver effective care. Twigg and McCullough (2014) [67] mentioned that empowerment of nurses is one of the components of consumer-centered care initiatives, whereby the workers are allowed to freely make decisions while improving their aged care and dementia skills. The staff members will be motivated to increase their involvement and control of any expected organizational change by understanding the techniques applied in consumer-centered care [68]. Thus, allowing staff autonomy in decision making of care rendered promotes commitment and job satisfaction.

According to Roos and Du Toit (2014) [69], as the staff becomes empowered and open-minded, they become aware that during organizational transformation entailing a system, other organizational system components will be affected in the process. It is unlikely that the staff within the aged care facilities will abandon their task-oriented care if nurse managers do not allow them to make decisions independently and learn from their failed judgements. Brownie, Horstmanshof, \& Garbutt (2014) [70] found that the learning environment is positively affected by nursing leadership, trust, and respect. As such, nations such as Australia, the UK, and the US, are continually researching management skills and 
leadership qualities that promote effective implementation of the consumer-centered care model [6] [67] [70].

Previous research studies indicate that effective management and leadership, mutual trust and respect between managers and their staff, and empowerment and support of the workers are associated with job satisfaction as well as with institutional commitment to aged care facility workers [47] [53] [71]. The structural empowerment of staff members is more influential than personal dispositions in nursing homes. In most aged care facilities in Australia and nursing homes in the U.S., structural empowerment, both formal and informal, that permits access to resources, influence, and staff support is highly regarded [67] [72]. Employee empowerment in each institution is associated with their commitment. The findings indicated that it is essential for nurse managers to include other staff members at all levels of decision-making in the organization to enhance the commitment of the workers to deliver quality care to the aged and dementia populations.

\section{Managers as Leaders}

Leadership and management play distinct roles in improving the quality of care in aged care facilities. According to Jeon et al. (2015) [13], leadership is more of developing a long-term vision and coming up with ways to encourage the managers and other staff members to work towards accomplishing any change process. Jeon et al. (2015) [13] defined management as the process of planning, strategizing, systematising and monitoring the way service delivery is done. The Leadership White Paper (2015) [73] highlighted that nurse managers participate in formal management positions whereas nurse leaders are not necessarily given any management role in an institution. It has been noted by Hurley and Hutchinson (2013) [74] that most nurses in Australia are not prepared to take up management roles when appointed to do so.

The Department of health in Australia has instituted a clinical management leadership framework for middle nurse managers delivering their duties in aged care facilities ([11]. The framework was instituted to allow senior managers to lead and manage the workforce to enhance the implementation of new initiatives. Van Wart (2013) [75] stated that for managers and leaders to take up the leadership challenge in enriching and enhancing the livelihoods of the workers, clinical leadership ought to be operationalised in a better way to capture the whole management structure. In the process of making clinical leadership operational, it is obligatory to clarify the roles of manager leaders in the establishment of quality care systems [76]. As accountability and independence take centre stage in a consumer-centered care organization, leaders are prone to emerge across all departments with the ability to identify areas of improvement to promote the implementation of new reforms and models [77] [78] [79] [80] [81]. In fact, within the consumer-centered care model, individuals are expected to support leadership in the care institution [82]. Effective leadership and management were cited to be the drivers of an organizational culture that is supportive during 
the implementation of new reforms and care models in aged care facilities.

\section{Summary}

The literature section has examined management and leadership during the implementation of reforms and care models; in this case, the consumer-centered care model in aged care facilities. The section presented the relationship between management and leadership, and organizational culture in relation to the implementation of care models and reforms in aged care facilities.

From the literature review, an organizational culture that supports workers and promotes respect and trust among the workers is likely to implement any care models and new reforms successfully. Collaboration among nurse managers, other workers, and, residents are also vital in the implementation process. Though identified as fundamental, management and leadership development in the residential aged care sector contains limited research materials. This study aims to identify strategies that make management and leadership effective during the implementation of plans and initiatives. Table 1 shows a summary of some sources included in the literature section.

Table 1. Summary of some of the sources included in literature section.

\begin{tabular}{|c|c|c|c|c|}
\hline Author/ aim & Type of source & Management/leadership strategies & Results & Data source \\
\hline $\begin{array}{c}\text { Singh, (2014). } \\
\text { Aim: providing in-depth } \\
\text { information on how one can } \\
\text { manage skills in a nursing facility. }\end{array}$ & Journal & $\begin{array}{l}\text { Embracing leadership qualities } \\
\text { including staff empowerment, } \\
\text { organization support, staff } \\
\text { recognition, staff training, etc. }\end{array}$ & & Google scholar \\
\hline $\begin{array}{l}\text { Taylor \& Donoghue (2015). } \\
\text { Aim: determining new ways of } \\
\text { providing services }\end{array}$ & Journal & $\begin{array}{l}\text { Promoting empowerment and } \\
\text { recognition of workers }\end{array}$ & $\begin{array}{l}\text { Empowerment and recognition } \\
\text { promotes improvements }\end{array}$ & Google scholar \\
\hline $\begin{array}{c}\text { Williams, Perillo, \& Brown (2015). } \\
\text { Aim: determining organizational } \\
\text { barriers to the implementation } \\
\text { process }\end{array}$ & Journal & $\begin{array}{l}\text { Creating a conducive workplace } \\
\text { setting }\end{array}$ & $\begin{array}{c}\text { Barriers to implementation are } \\
\text { associated with nature of work place } \\
\text { setting }\end{array}$ & Google scholar \\
\hline $\begin{array}{l}\text { You, Dunt, \& Doyle (2017). } \\
\text { Aim: exploring perceived changes } \\
\text { in practice }\end{array}$ & Journal & Promoting cultural changes & $\begin{array}{l}\text { Empowerment is vital in } \\
\text { supporting and sustain } \\
\text { organizational changes }\end{array}$ & Google scholar \\
\hline $\begin{array}{l}\text { Yu et al., (2013). } \\
\text { Aim: investigating the effects of } \\
\text { introducing new records in } \\
\text { residential care and their courses }\end{array}$ & Journal & $\begin{array}{c}\text { Enhancing a conducive work } \\
\text { environment }\end{array}$ & $\begin{array}{c}\text { Effects include lack of proper } \\
\text { communication, poor } \\
\text { information management, difficulty } \\
\text { in retrieving information }\end{array}$ & NCBI database \\
\hline $\begin{array}{l}\text { Zimmerman, Shier, \& Saliba } \\
\qquad \begin{array}{l}(2014) \text {. } \\
\text { Aim: to improve the quality of care }\end{array}\end{array}$ & Journal & $\begin{array}{c}\text { Changing the nursing home } \\
\text { culture }\end{array}$ & $\begin{array}{l}\text { Empowering nurses, training } \\
\text { nurses, promoting effective } \\
\text { communication, promoting } \\
\text { effective retrieval of information. }\end{array}$ & $\begin{array}{l}\text { Gerontological } \\
\text { Society of America } \\
\text { database }\end{array}$ \\
\hline $\begin{array}{c}\text { West et al. (2014). } \\
\text { Aim: exploring how both } \\
\text { organizational climate and culture } \\
\text { influence performance }\end{array}$ & handbook & $\begin{array}{l}\text { Organizational climate and } \\
\text { cultural changes }\end{array}$ & $\begin{array}{l}\text { The subculture of team working } \\
\text { improves performance }\end{array}$ & $\begin{array}{l}\text { Oxford handbook } \\
\text { online database }\end{array}$ \\
\hline $\begin{array}{l}\text { WA Department of Health. (2015). } \\
\text { Aim: delivering a safe, high quality, } \\
\text { sustainable health system }\end{array}$ & Health report & Changing the work environment & $\begin{array}{l}\text { Respect, integrity, teamwork and } \\
\text { good leadership }\end{array}$ & $\begin{array}{c}\text { Government of } \\
\text { Western Australia } \\
\text { database }\end{array}$ \\
\hline
\end{tabular}




\section{Continued}

\begin{tabular}{|c|c|c|c|c|}
\hline $\begin{array}{l}\text { Van Biljon \& Roos (2015). } \\
\text { Aim: to determine the significance } \\
\text { of the quality of life model in a } \\
\text { work environment }\end{array}$ & Journal & Changing the work environment & $\begin{array}{l}\text { Quality of Life model regards } \\
\text { coping with challenges and being } \\
\text { mindful of others }\end{array}$ & $\begin{array}{c}\text { Google scholar } \\
\text { database }\end{array}$ \\
\hline $\begin{array}{c}\text { Stokoe et al. (2016). } \\
\text { Aim: exploring issues in the } \\
\text { management of residential aged } \\
\text { care facilities }\end{array}$ & Journal & Promoting organizational culture & $\begin{array}{c}\text { Issues include communication } \\
\text { barriers, poor staff awareness and } \\
\text { nursing staff mix }\end{array}$ & NCBI database \\
\hline $\begin{array}{l}\text { Soltanifar \& Russell (2012). } \\
\text { Aim: offering evidence-based } \\
\text { recommendations for best practice }\end{array}$ & Journal & Enhancing best practice & $\begin{array}{l}\text { Changes in the organizational } \\
\text { environment are key in successfully } \\
\text { implementing new programs }\end{array}$ & NCBI database \\
\hline $\begin{array}{c}\text { Pines et al. (2013). } \\
\text { Aim: describing trends in } \\
\text { use of care services like } \\
\text { emergency services }\end{array}$ & Journal & Changes in service delivery & $\begin{array}{l}\text { It addresses demands for execution } \\
\text { of new care services }\end{array}$ & NCBI database \\
\hline $\begin{array}{l}\text { Ottmann et al. (2013). } \\
\text { Aim: to determine user } \\
\text { preferences for and satisfaction } \\
\text { with consumer-directed care } \\
\text { programmes }\end{array}$ & Journal & Staff training and empowerment & $\begin{array}{l}\text { Workers are satisfied if they are } \\
\text { empowered to understand them }\end{array}$ & NCBI database \\
\hline $\begin{array}{l}\text { Kaasalainen et al. (2014). } \\
\text { Aim: exploring experiential learning } \\
\text { strategy to increase the capacity of } \\
\text { Personal support of workers related } \\
\text { to their training, and how they } \\
\text { want their experience changed }\end{array}$ & Journal & Staff support and training & $\begin{array}{l}\text { Care education gives the staff } \\
\text { confidence and promotes staff } \\
\text { commitment }\end{array}$ & NCBI database \\
\hline $\begin{array}{l}\text { Aim: assessing the impact of safety } \\
\text { climate among lone workers }\end{array}$ & Journal & Enhancing the work environment & $\begin{array}{l}\text { level of job satisfaction and } \\
\text { engagement and wish to support } \\
\text { new applications. }\end{array}$ & NCBI database \\
\hline
\end{tabular}

\section{Results}

This section presents the results of the study from the secondary data sources identified. The literature review and findings are further elaborated in this section. A summary of the sources included in analyzing the results is included in Table 2.

\section{Perceptions of Managerial Leadership}

Any positive feelings towards the managerial leadership from the workers are associated with increased job satisfaction as well as nurse retention across the aged care facilities, thereby reducing unnecessary recruitment costs [11]. To have positive feelings among the workers, managers ought to create a conducive environment in which they can relax and avoid the office pressures. A review of nurse retention by Twigg and McCullough (2014) indicated that poor support and recognition as a result of poor leadership and management triggers nurses' turnover. Effective leadership relates to creating a good working environment for the workers. 
Table 2. Summary of the sources included in results.

\begin{tabular}{|c|c|c|c|c|c|}
\hline Author/aim & Study design & Setting & $\begin{array}{l}\text { Leadership } \\
\text { frameworks/ } \\
\text { strategies }\end{array}$ & Outcomes & Data source \\
\hline $\begin{array}{l}\text { Jeon et al. (2015). } \\
\text { Aim: Determining the } \\
\text { legitimacy of the clinical } \\
\text { leadership framework }\end{array}$ & $\begin{array}{l}\text { A Delphi } \\
\text { method }\end{array}$ & $\begin{array}{l}\text { Residential aged care } \\
\text { facilities in rural and } \\
\text { metropolitan settings }\end{array}$ & $\begin{array}{l}\text { Clinical Leadership } \\
\text { Qualities } \\
\text { Framework. }\end{array}$ & $\begin{array}{l}\text { After the consultation, the } \\
\text { suitability and face validity of the } \\
\text { leadership framework was } \\
\text { established. }\end{array}$ & $\begin{array}{l}\text { Survey on } \\
\text { Sixty-nine experts } \\
\text { in aged care } \\
\text { facilities }\end{array}$ \\
\hline $\begin{array}{l}\text { Twigg \& McCullough } \\
\text { (2014). } \\
\text { Aim: To identify strategies in } \\
\text { the literature supporting } \\
\text { nurse retention through } \\
\text { enhancement of positive } \\
\text { work environments }\end{array}$ & $\begin{array}{l}\text { Literature } \\
\text { review }\end{array}$ & & $\begin{array}{l}\text { Creating a positive } \\
\text { work environment }\end{array}$ & $\begin{array}{l}\text { Strategies creating conducive } \\
\text { work environment include; staff } \\
\text { empowerment, shared governance } \\
\text { structure, staff independence, } \\
\text { leadership support, and skill mix } \\
\text { and organizational relationships }\end{array}$ & $\begin{array}{l}\text { Medline, and } \\
\text { ProQuest } \\
\text { databases }\end{array}$ \\
\hline $\begin{array}{l}\text { Shield et al. (2014). } \\
\text { Aim: understanding the } \\
\text { process and reasons for } \\
\text { promoting culture change } \\
\text { (CC) practices }\end{array}$ & Survey & $\begin{array}{l}4149 \text { United States } \\
\text { NHS }\end{array}$ & $\begin{array}{c}\text { Promoting cultural } \\
\text { change practices }\end{array}$ & $\begin{array}{l}\text { Reasons for affecting CC practices } \\
\text { vary; strategies for implementing } \\
\text { CC practices are different; NHS } \\
\text { consider staff mix when } \\
\text { implementing the practices; } \\
\text { enactment of changes is } \\
\text { challenging, and strategies for } \\
\text { change are tailored to the } \\
\text { challenges encountered; training } \\
\text { and effective communication are } \\
\text { vital; staff leadership is key to } \\
\text { enacting changes. }\end{array}$ & $\begin{array}{l}\text { NH Directors of } \\
\text { Nursing } \\
\text { (DONs) and } \\
\text { Administrators } \\
\text { (NHAs) }\end{array}$ \\
\hline $\begin{array}{l}\text { Shier et al. (2014) } \\
\text { Aim: to find out ways of } \\
\text { promoting cultural changes } \\
\text { in organizations }\end{array}$ & $\begin{array}{l}\text { A comprehensive } \\
\text { review of } \\
\text { peer-reviewed and } \\
\text { grey literature }\end{array}$ & & $\begin{array}{l}\text { Promoting cultural } \\
\text { changes }\end{array}$ & $\begin{array}{l}\text { 1 Close relationships, staff support, } \\
\text { appreciation, staff training }\end{array}$ & Online databases \\
\hline $\begin{array}{l}\text { Prgomet et al. (2017) } \\
\text { Aim: to study front line } \\
\text { workers and their } \\
\text { perceptions on altering } \\
\text { policy landscape }\end{array}$ & Survey & $\begin{array}{l}\text { Australian aged care } \\
\text { organization }\end{array}$ & $\begin{array}{l}\text { Promoting policy } \\
\text { changes }\end{array}$ & $\begin{array}{l}\text { Altering policy landscape } \\
\text { enhances communication; } \\
\text { facilitates front line commitment; } \\
\text { enhances management of } \\
\text { organizational changes }\end{array}$ & $\begin{array}{l}\text { Care workers and } \\
\text { six case managers }\end{array}$ \\
\hline $\begin{array}{l}\text { Ouyang et al. (2015). } \\
\text { Aim: to explore the effect of } \\
\text { psychological empowerment } \\
\text { and organizational } \\
\text { commitment. }\end{array}$ & Survey & $\begin{array}{l}\text { Tertiary hospitals in } \\
\text { China }\end{array}$ & $\begin{array}{l}\text { Promoting } \\
\text { organizational } \\
\text { commitment }\end{array}$ & $\begin{array}{l}\text { Nurse satisfaction is influenced by } \\
\text { psychological empowerment. } \\
\text { Organizational commitment } \\
\text { promotes the implementation of } \\
\text { new initiatives. }\end{array}$ & $\begin{array}{l}\text { A questionnaire } \\
\text { filled by } 726 \text { nurses } \\
\text { from tertiary } \\
\text { hospitals }\end{array}$ \\
\hline $\begin{array}{l}\text { Oliver et al. (2014). } \\
\text { Aim: describing perceptions } \\
\text { of structural empowerment }\end{array}$ & Survey & $\begin{array}{l}\text { The large healthcare } \\
\text { system in the } \\
\text { North-eastern United } \\
\text { States }\end{array}$ & $\begin{array}{c}\text { Promoting } \\
\text { organizational } \\
\text { empowerment }\end{array}$ & $\begin{array}{l}\text { Structural empowerment comes } \\
\text { to a result of staff support, formal } \\
\text { power, and informal power. }\end{array}$ & $\begin{array}{l}\text { Interview with } \\
\text { Clinical nurse } \\
\text { managers }\end{array}$ \\
\hline $\begin{array}{c}\text { Van der Voet (2014) } \\
\text { Aim: examining efficiency as } \\
\text { well as specificity of change } \\
\text { management }\end{array}$ & Survey & $\begin{array}{l}\text { Dutch public } \\
\text { organization }\end{array}$ & $\begin{array}{l}\text { Fostering } \\
\text { organizational } \\
\text { changes }\end{array}$ & $\begin{array}{l}\text { The leadership role is important } \\
\text { during organizational change }\end{array}$ & Interviews \\
\hline $\begin{array}{l}\text { Bennett et al., (2014). } \\
\text { Aim: exploring perspectives } \\
\text { of mealtime management }\end{array}$ & Survey & $\begin{array}{l}\text { Five Residential aged } \\
\text { care facilities }\end{array}$ & $\begin{array}{l}\text { Embracing policy } \\
\text { changes }\end{array}$ & $\begin{array}{l}\text { Limited consideration of meal } \\
\text { times in policy is a barrier in } \\
\text { mealtime management. }\end{array}$ & Interviews \\
\hline
\end{tabular}




\section{Continued}

\begin{tabular}{|c|c|c|c|c|c|}
\hline $\begin{array}{l}\text { Hurley \& Hutchinson } \\
\text { (2013). } \\
\text { Aim: highlighting the } \\
\text { significance of strengthening } \\
\text { leadership capability. }\end{array}$ & $\begin{array}{l}\text { Critical literature } \\
\text { review }\end{array}$ & & $\begin{array}{l}\text { Transforming the } \\
\text { work environment }\end{array}$ & $\begin{array}{l}\text { Effective nurse leadership affects } \\
\text { the work environment and its } \\
\text { goals }\end{array}$ & Online database \\
\hline $\begin{array}{l}\text { Jeon et al. (2013). } \\
\text { Aim: establishing the } \\
\text { effectiveness of the CLiAC } \\
\text { program }\end{array}$ & $\begin{array}{l}\text { Randomised } \\
\text { controlled trial } \\
\text { testing }\end{array}$ & $\begin{array}{l}\text { Residential and } \\
\text { community aged care } \\
\text { sites }\end{array}$ & $\begin{array}{c}\text { Embracing good } \\
\text { leadership qualities }\end{array}$ & $\begin{array}{l}\text { Clinical Leadership in Aged Care } \\
\text { enhances the manager's } \\
\text { leadership qualities. }\end{array}$ & $\begin{array}{l}\text { Residential and } \\
\text { community aged } \\
\text { care sites }\end{array}$ \\
\hline $\begin{array}{l}\text { McCormack et al. (2012). } \\
\text { Aim: highlight similarities } \\
\text { and differences between the } \\
\text { different leadership models. }\end{array}$ & Literature review & & $\begin{array}{l}\text { Appreciating } \\
\text { individuals }\end{array}$ & $\begin{array}{l}\text { Management and leadership } \\
\text { models and frameworks need to } \\
\text { regard personhood. }\end{array}$ & Online databases \\
\hline $\begin{array}{l}\text { Cicolin et al. (2014). } \\
\text { Aim: to determine if nurse } \\
\text { empowerment is correlated } \\
\text { with their satisfaction }\end{array}$ & Systematic review & & $\begin{array}{c}\text { Promoting staff } \\
\text { empowerment }\end{array}$ & $\begin{array}{c}\text { Structural empowerment and } \\
\text { psychological empowerment } \\
\text { influence nurse satisfaction } \\
\text { differently }\end{array}$ & Online databases \\
\hline
\end{tabular}

Employees are often accustomed to "routines" which hinders the implementation of a new program in the organization. According to the review, abandoning office comfort is one way of transforming the organization culture in relation to governance to give room for better and strategic decisions that will ensure the change process is successfully implemented and utilised [79]. Moving out of the central office is aimed at diminishing "noise" that symbolises the employees' work habits [36]. Despite seeing the central office as the hub of an organization from where directives originate, the managers should also view it as a hub for offering support to all workers in the aged care facility. It is evident from the review that, for efficient organization-wide execution of the consumer-centered care model, it is obligatory to change the governance whereby the central office is left open for queries and clarifications [72]. The open design organizational structure promotes a conducive working environment that fosters interpersonal interactions among the change agents and the other workers [48]. According to the review, it is advisable to change the central office structure if it is perceived to be inconsistent in promoting reforms and innovative programs. In agreement with changing governance structure, Van der Voet (2014) and Bennett et al. (2014) acknowledged that such an initiative should be done alongside with other initiatives that promote equality and eliminate biases such as removing personalised parking lots, promoting same meal times and embracing one organizational uniform.

\section{Organizational Management and Leadership}

Effective management and leadership are determined by the existing organizational leadership that gives managers and leaders the confidence in their leadership style as a result of being allocated enough resources. The aim of this is to ensure that they deliver their mandate in providing support to the staff [74]. Some of the essential resources that are offered by the leadership of an organization include skill mix among workers, human resource practices and 
administrative support, and effective communication of policy changes.

As the organization leadership introduces cultural changes, they promote innovative ideas from the managerial perspective, thereby transforming their workers' working habits, and abandoning their traditional work practices and paving the way for innovation [71]. Therefore, it true that changing the usual governance structure of the organizational leadership will promote a healthy and conducive work environment that increases employee job satisfaction and commitment in any expected organizational change. Such an environment supports the "yes culture" whereby staff will not be opposed to any transformational change that comes their way. The culture will ensure emerging care programs are effectively and flexibly implemented. To promote such a culture in an organization, Roos and $\mathrm{Du}$ Toit (2014) recognised that the organizational leadership and management must offer their employees autonomy and to enhance their capacity to take part in decision-making. The "yes culture", that aims at nurses" job satisfaction should include "top-down" and "bottom-up" collaborative management strategies to ensure the effectiveness of the implementation process [71]. This would enhance communication and create a good relationship between leaders and workers.

\section{Features/models of Managerial Leadership}

According to the reviews of the leadership attributes including effective communication, flexibility, professional expertise in promoting a conducive work environment in which recognition is upheld and empower the staff [11] [61] [81] [82]. Significant studies on effective leadership focus on highly desirable managerial attributes among the manager leaders. The attributes include openness, respect mentoring, supportive and inspiring management, and emotional intelligence [71] [72]. It was also found that optimism is considered to be a managerial attribute that inspires other workers by increasing their satisfaction and diminishing turnover.

The leadership approach employed in aged care organizations correlates with job satisfaction, nurses' retention, and workforce motivation [13]. Cicoloni, Comparcini and Simonett (2014) [61] suggested that participative leadership is recommended when an organization is embracing a significant change in the care model as the employees are given the autonomy in decision making and implementing change. However, Doody and Doody (2012) [83] mentioned that transformational leadership is the preferred leadership style as it was found to influence the employees with organizational culture to create a supportive working environment that ensured a satisfied and sustainable workforce. Managers and leaders with the ability to empower and motivate other workers will model organizational values and work ethics to address the needs of the workers. Effective leadership was found to be the key determining factor of successful implementation of new care programs in aged care facilities.

\section{Discussion}

Effective management and leadership in an organization are based on an indi- 
vidual's ability to devise successful strategies for managing expected change. It is essential to understand the needs of different people that the leader aims to amplify their capacity in supporting any new program implementation. In agreement, Hutchinson and Hurley (2013) [82] stated that organizations understanding the meaning of strategic management and leadership when planning an implementation exercise are prone to offer a conducive environment in which people share their opinions. This is so to ensure that the exercise is successfully completed. The managers involved in the interview attributed their success in executing projects to the changes embraced in the organizational culture that aimed at improving organization-wide practice. Jeon et al. (2015) [13] acknowledged that management and leadership from all aged care units are required during the implementation of any program, including the consumer-centered care model.

An effective leader is identified as the one leading from the front. Jeon et al. (2015) [13] mentioned that clinical leadership is all about formulating a clear vision and optimistic motive geared towards encouraging and guiding individuals towards organizational change. Significant research studies aiming to enhance service delivery in residential aged care homes across the world indicate that the extent of success in implementation of any new program relies on the managers' capacity and leadership abilities to offer support to other workers [31] [37] [63] [70]. Management and leadership approaches are significant when aged care homes are trying to adopt and implement new care programs. Leadership is linked to the consumer-centered philosophy that is obligatory in determining a strategic direction that ought to guarantee improved aged care as well as drive appropriate transformations in aged care homes.

It is also fundamental to value the people surrounding an individual. Valuing people starts from leaving one's comfort zone and supporting others in achieving common organizational goals. Most top managers embrace open office structure in which the personnel efforts are supported by management [67]. In this view, many organizations have constituted vision and mission statements that capture the needs of various employees. Addressing the needs of individuals in a free environment where they can make decisions autonomously is fundamental because it promotes their commitment and confidence. Additionally, transforming the traditional management and leadership structure is vital in changing employees' work habits. Furthermore, it is acknowledged that embracing change by the management to perform a certain task is aimed at accomplishing employee's needs to support the implementation of new programs [58] [82] [84]. This marks a crucial step towards accomplishing the vision and mission statements of organizations by addressing the rights and freedoms of individuals.

Organizational support is often aimed at enhancing the implementation of emerging programs. This support can be realistic if management and leadership offer a practical framework for execution of the programs. As noted by Hutchinson and Hurley (2013) [82], a vision emphasising organizational aspirations needs to be aligned with specific goals. Even if nurse managers are experienced, 
they are prone to struggle as they attempt to execute the consumer-centered care model in their facilities when they lack effective leadership that offers support to their efforts. If an organization is meant to deliver services through consumer-centered care, then it is the duty of the managers and leaders to offer utmost quality in their leadership skills that ensure the approach is successful [13]. According to Etherton-Beer et al. (2017) [16], the adoption of new strategies and practices to support any proposed change is never easy. The major issue is how to ensure the organizational workforce accepts and works towards supporting the strategies and practices. Innovative ideas cannot be accepted and positively supported if managers and leaders in an aged care facility do not address workforce needs.

From the review, changing the work environment is fundamental if an individual wish to implement a new plan successfully. As the managers prepare for new care programs, their efforts are based on providing the workforce with information, which shows that the new project is not a mere gesture of facility improvement but a project designed to improve service delivery by the workforce [67]. During the implementation of new programs, managers may engage in a "top-down" leadership approach that is complemented with "bottom-up" opportunities. The combined approach has been found to encourage as many staff members as possible to give their opinions in relation to program implementation. Conway et al. (2015) [32] advised that all organizational levels are supposed to be included and show commitment towards the implementation of any programs. For effective leadership, individuals are obliged to ensure organizational policies are in line with leadership development initiatives with the ability to deliver essential funds for both structural as well as psychological empowerment among the workers.

\section{Conclusions}

The current study was aimed at developing strategies that summarize the literature both in Australia and overseas on frameworks for effective management and leadership in the aged care sector, considering relevant regulation, legislation, and funding. It is evident from the study that effective organizational culture supports the implementation of programs in an organization where the managers and leaders alter the organizational framework. Despite the implementation of new care programs requiring the involvement of leadership from all levels, managers and other workers are likely to face battles with staff if there is no effective organizational support. Organizational support is fundamental in pursuing implementation of any program in aged care organizations. The organizational support can be achieved through several ways, including transforming the organizational culture that was promoted through changing the organizational system, embracing "yes culture" and changing employees work habits and the way they perform their assigned tasks. Without changing the usual work habits in an organization, it is unlikely that the workers and 
managers will be motivated to commit to accomplishing their roles in the implementation process. This is because individuals will always be reluctant to change when they perform the task by habit.

Aged care staff members are always encouraged by organizational managers to be responsible when it comes to the implementation of care programs that are consumer-centered. They promote the new organizational "yes culture" to motivate individuals so that they will not deter from achieving the implementation objective. Organizational management and leadership were investigated in the continually improving area of aged care service delivery. Around the world, aged care is moving from the traditional care service delivery to the more consumer-centered care programs whose main aim is to effectively address residents' needs as well as workers' needs. Through continuous improvement of care homes, structural transformations are expected to take place, with their success based on the management and leadership strategies employed before and after the implementation.

It is clear from the study that when individuals wish to successfully sustain the implementation of new aged care programs in residential facilities, they ought to engage all stakeholders in committing to the project. A shared initiative will always see a care improvement project succeed. From the organization perspective, an individual was required to think critically as they adopted the new programs for future service delivery in aged care facilities, where addressing the needs of all stakeholders is the key to successful implementation. With this view, it is obligatory to alter the organization culture and give room for new work habits that are linked to enhancing innovation. Altering organizational culture requires nurse managers to be flexible in their governance and offer support to all stakeholders involved in the implementation of various care programs. The new organizational culture is also expected to promote autonomous decision-making among other workers with the aim of increasing employee job satisfaction and commitment.

It is also important to note that all best practices analyzed here supported the transformation of organizational culture, including changing individuals' work habits, changing systems, embracing good leadership qualities, and adopting effective managerial attributes such as staff empowerment. Changing the organizational culture will offer individuals an opportunity to accommodate innovative approaches that will be necessary for the new programs implemented in aged care facilities. If the managers do not foster a good working environment by changing the traditional work habits, then they are prone to fail in delivering their leadership mandate pertaining to the implementation of the new care programs. As seen earlier, changing the culture of an organization can be achieved through minor activities such as all staff members including senior management to wear a uniform to work. Other strategic provisions include upholding top leadership qualities, such as empowering staff and giving staff members autonomy in making decisions related to the implementation of initiatives. These strategies and practices were found to have a more enormous influence on how 
staff members support the implementation as well as the success of new programs after implementation. If staff members are encouraged to improve program implementation, then managers and leaders would fulfill their organizational goals and visions aimed at providing quality care to the aging populations through aged care facilities.

Therefore, it is clear from the discussions above that strategies and practices employed to transform the organizational culture will significantly influence the implementation of any expected care initiatives. The strategies and practices are supposed to be person-oriented to address the rights of people efficiently, thereby empowering them to commit their efforts to ensure that a given objective is accomplished. Committed and empowered workers will always do their best to make sure their mandate is appropriately and effectively delivered.

\section{Recommendations}

\section{Recommendations at a National Level for Aged Care Providers}

Today, with increased demand for aged care facilities as a result of the increasing number of ageing population in the world and more so for those ailing from dementia, residential aged care homes ought to embrace the consumer-centered care approach since it improves the quality of care. For successful implementation of consumer-centered care, aged care homes must develop their commitment to funds and operational changes in their governance so that they can offer support to workers involved in the implementation of new programs. Strategic, operational changes include altering policies, systems, and procedures within the organization to assist individuals using the consumer-centered care program. In addition to the usual funding of aged care facilities, managers and leaders should offer additional resources such as staff rewards and recognition to employees to facilitate the implementation of new care programs to promote continuity in service care improvement. These resources are vital since they foster a healthy working environment in which employees learn to trust and commit themselves towards each other to uphold collaboration.

\section{Recommendations at an Organizational Level for Aged Care Providers}

For the organizations to be truly committed to the new care programs, they should improve the organizational culture in which employees are given freedom to make decisions about the implementation of the care programs. Staff members ought to be provided with the capabilities to discern the organizational changes that are expected, and their role in successfully implementing the changes. It should be the duty of the management and leadership to promote staff empowerment by offering staff training to improve skills for some new programs. Empowerment should be encouraged to limit employee turnover as a result of new care programs whereby staff have no knowledge of the initiative to deliver quality care in aged care homes.

Managers should play a role of "culture carriers" in aged care facilities to ensure the correct organizational culture is cultivated to support the implementa- 
tion of new care programs. For aged care organizations to promote new care programs, managers should be equipped with practical leadership skills and offered legitimate authority to flexibly support organizational transformation without hurting any stakeholder or employee. In the contemporary world, management ought to adopt consumer-centered leadership styles to encourage a conducive work environment in which employees are satisfied and committed to upholding collaboration in ensuring the programs are successfully implemented. In addition to leadership styles, management qualities are also required. Managers ought to be humble, committed, caring, visionary, and welcoming, aiming to capture individuals' willingness to cultivate effective strategies and practices to adopt new programs. Managers should embrace 360-degree feedback to enhance communication with other stakeholders, which is the key to successful execution of any program. In this era of new care programs, aged care homes ought to institute project teams to establish areas of improvement associated with management and leadership to avoid failure in implementation of the new programs. This will thereby avoid a failed initiative to offer quality care to ageing residents across aged care homes. The members of the project teams should be recruited from various aged care facility departments to allow as many people as possible to have a better understanding of the expected transformations designed to promote successful implementation of new initiatives.

The management and leadership of aged care organizations should fully commit to the organizational objective and mission by aligning service delivery with changing needs of workers and aged care facilities as a result of expected cultural changes. In general, the aged care organizations' management and leadership ought to understand how they can effectively lead organizational change across aged care homes without affecting employees' emotions and functionality. For effective cultural changes, management and leadership ought to conduct a thorough investigation of the structural factors that need to be altered to promote organizational transformation. The organizations should assess and monitor the impact of the above recommendations on care service delivery on the ageing and dementia populations at all organizational levels.

\section{Recommendations for Future Research}

With the aim of trying to understand the strategies and practices employed to support the implementation of new programs such as consumer-centered care across the aged care facilities, the current study used secondary sources capturing large aged care facilities. For future research, similar aims should be recommended for research studies involving small aged care facilities, or the studies must be conducted to understand the operations of many aged care homes to enhance generalisation of the research findings across some aged care facilities. If the future research studies are conducted using secondary sources, the range of the sources should be increased to cover more than five years to understand effective management and leadership in new program implementation. Lastly, future research to understand effective management and leadership should be 
based on primary sources to understand the problem right in its environment. Hence, the study should focus on staff own satisfaction in providing consumer-centered care and include the different perspectives of patients, families, and communities who are at the receiving end.

\section{Acknowledgements}

The research study included members of the reference group, international professionals, and experts in research related to leadership and management in aged care facilities who gave their advice on effective research methods and suggestions on the research findings as well as recommendations. The final draft of the research study was reviewed by Singapore nurse managers selected for consultation. Appreciation goes to them for giving constructive feedback that was a motivation to proceeding with the research activity.

\section{Conflicts of Interest}

The author declares no conflicts of interest regarding the publication of this paper.

\section{References}

[1] Commonwealth Department of Social Services (2014) Residential Care Manual. Canberra.

[2] Broad, J.B., Ashton, T., Gott, M., McLeod, H., Davis, P.B. and Connolly, M.J. (2015) Likelihood of Residential Aged Care Use in Later Life: A Simple Approach to Estimation with International Comparison. Australian and New Zealand Journal of Public Health, 39, 374-379. https://doi.org/10.1111/1753-6405.12374

[3] Khalik, S. (2016) 30,000 More Healthcare Workers Needed by 2020 to Cater for Singapore's Ageing Population: Health Ministry. The Straits Times.

http://www.straitstimes.com/singapore/health/30000-more-healthcare-workers-nee ded-by-2020-to-cater-for-singapores-ageing

[4] Chan, L.E. (2016) Healthcare Experts Concerned over Lack of Manpower in Long-Term Care Sector. Channel News Asia.

http://www.hrinasia.com/news/healthcare-experts-concerned-over-lack-of-manpow er-in-long-term-care-sector/

[5] Pol-Grevelink, A., Jukema, J.S. and Smits, C.H.M. (2012) Person-Centred Care and Job Satisfaction of Caregivers in Nursing Homes: A Systematic Review of the Impact of Different Forms of Person-Centred Care on Various Dimensions of Job Satisfaction. International Journal of Geriatric Psychiatry, 27, 219-229. https://doi.org/10.1002/gps.2719

[6] Aarons, G.A., Ehrhart, M.G., Farahnak, L.R. and Sklar, M. (2014) Aligning Leadership across Systems and Organizations to Develop a Strategic Climate for Evidence-Based Practice Implementation. Annual Review of Public Health, 35, 255-274. https://doi.org/10.1146/annurev-publhealth-032013-182447

[7] Kumar, R.D.C. and Khiljee, N. (2016) Leadership in Healthcare. Anaesthesia \& Intensive Care Medicine, 17, 63-65. https://doi.org/10.1016/j.mpaic.2015.10.012

[8] Dixon, J., King, D. and Knapp, M. (2016) Advance Care Planning in England: Is There an Association with Place of Death? Secondary Analysis of Data from the $\mathrm{Na}$ - 
tional Survey of Bereaved People. BMJ Supportive \& Palliative Care. https://doi.org/10.1136/bmjspcare-2015-000971

[9] Hugo, G. (2014) The Demographic Facts of Ageing in Australia: Patterns of Growth. APMRC Policy Briefs.

https://www.adelaide.edu.au/apmrc/pubs/policybriefs/APMRC Policy Brief Vol 2 2.pdf

[10] WA Department of Health (2015) WA Health Strategic Intent 2015-2020. Government of Western Australia.

[11] Jeon, Y.H., Simpson, J.M., Chenoweth, L., Cunich, M. and Kendig, H. (2013) The Effectiveness of an Aged Care Specific Leadership and Management Program on Workforce, Work Environment, and Care Quality Outcomes: Design of a Cluster Randomised Controlled Trial. Implementation Science, 8, 126.

https://doi.org/10.1186/1748-5908-8-126

[12] Kaine, S. and Ravenswood, K. (2014) Working in Residential Aged Care: A Trans-Tasman Comparison. New Zealand Journal of Employment Relations, 38, 33.

[13] Jeon, Y.H., Conway, J., Chenoweth, L., Weise, J., Thomas, T.H. and Williams, A. (2015) Validation of a Clinical Leadership Qualities Framework for Managers in Aged Care: A Delphi Study. Journal of Clinical Nursing, 24, 999-1010. https://doi.org/10.1111/jocn.12682

[14] Zimmerman, S., Shier, V. and Saliba, D. (2014) Transforming Nursing Home Culture: Evidence for Practice and Policy. The Gerontologist, 54, S1-S5. https://doi.org/10.1093/geront/gnt161

[15] Frey, R., Boyd, M., Foster, S., Robinson, J. and Gott, M. (2015) Whats the Diagnosis? Organizational Culture and Palliative Care Delivery in Residential Aged Care in New Zealand. Health \& Social Care in the Community, 24, 450-462. https://doi.org/10.1111/hsc. 12220

[16] Etherton-Beer, C., Venturato, L. and Horner, B. (2017) Organizational Culture and Workforce Contributions to Quality in Long-Term Care: Organizational Culture Change in Residential Aged Care. Innovation in Aging, 1, 702-703.

https://doi.org/10.1093/geroni/igx004.2516

[17] Loveday, B. (2013) Leadership for Person-Centred Dementia Care. Jessica Kingsley, London.

[18] Zhao, J., Gao, S., Wang, J., Liu, X. and Hao, Y. (2016) Differentiation between Two Healthcare Concepts: Person-Centered and Patient-Centered Care. International Journal of Nursing Sciences, 3, 398-402. https://doi.org/10.1016/j.ijnss.2016.08.009

[19] Dwyer, D. (2014) Experiences of Registered Nurses as Managers and Leaders in Residential Aged Care Facilities. International Journal of Evidence-Based Healthcare, 12, 187. https://doi.org/10.1097/01.XEB.0000455173.43488.61

[20] Saunders, M., Lewis, P. and Thornhill, A. (2014) Research Methods for Business Students. Pearson Education Limited, London.

[21] Taylor, C. and Donoghue, J. (2015) New Ways to Provide Community Aged Care Services. Australasian Journal on Ageing, 34, 199-200. https://doi.org/10.1111/ajag.12207

[22] Bryman, A. and Bell, E. (2015) Business Research Methods. Oxford University Press, Oxford.

[23] Gray, D.E. (2016) Doing Research in the Business World. SAGE, London.

[24] Bell, J. and Waters, S. (2014) Doing Your Research Project: A Guide for First-Time Researchers. McGraw-Hill Education, Maidenhead. 
[25] Smith, J.A. (2015) Qualitative Psychology: A Practical Guide to Research Methods. Sage, London.

[26] Briner, R.B. and Denyer, D. (2012) Systematic Review and Evidence Synthesis as a Practice and Scholarship Tool. In: Rousseau, D.M., Ed., Handbook of Evidence-Based Management. Companies, Classrooms and Research, Oxford University Press, Oxford, 112-129. https://doi.org/10.1093/oxfordhb/9780199763986.013.0007

[27] Snilstveit, B., Oliver, S. and Vojtkova, M. (2012) Narrative Approaches to Systematic Review and Synthesis of Evidence for International Development Policy and Practice. Journal of Development Effectiveness, 4, 409-429. https://doi.org/10.1080/19439342.2012.710641

[28] Soltanifar, S. and Russell, R. (2012) The National Institute for Health and Clinical Excellence (NICE) Guidelines for Caesarean Section, 2011 Update: Implications for the Anaesthetist. International Journal of Obstetric Anesthesia, 21, 264-272. https://doi.org/10.1016/j.ijoa.2012.03.004

[29] Palinkas, L.A., Horwitz, S.M., Green, C.A., Wisdom, J.P., Duan, N. and Hoagwood, K. (2015) Purposeful Sampling for Qualitative Data Collection and Analysis in Mixed Method Implementation Research. Administration and Policy in Mental Health and Mental Health Services Research, 42, 533-544. https://doi.org/10.1007/s10488-013-0528-y

[30] Kelly, D., Sampson, C. and Kelly, V. (2015) Treated like an Equal, Treated with Respect: A Sustainable Co-Design and Systems Thinking Approach to Aged Care Reform That Empowers Older People as a Valuable Community Resource. Unmaking Waste 2015 Conference Proceedings, Adelaide, 22-24 May 2015, 185-195.

[31] Bennett, M.K., Ward, E., Scarinci, N. and Waite, M. (2014) Perspectives on Mealtime Management in Residential Aged Care: Insights from a Cross-Disciplinary Investigation. Journal of Nutrition in Gerontology and Geriatrics, 33, 325-390. https://doi.org/10.1080/21551197.2014.963275

[32] Conway, J., Higgins, I., Hullick, C., Hewitt, J. and Dilworth, S. (2015) Nurse-Led ED Support for Residential Aged Care Facility Staff: An Evaluation Study. International Emergency Nursing, 23, 190-196. https://doi.org/10.1016/j.ienj.2014.11.005

[33] Meng, X. and Boyd, P. (2017) The Role of the Project Manager in Relationship Management. International Journal of Project Management, 35, 717-728. https://doi.org/10.1016/j.ijproman.2017.03.001

[34] O’Leary, Z. (2017) The Essential Guide to Doing Your Research Project. SAGE Publications Ltd., London.

[35] Creswell, J.W. (2014) Research Design: Qualitative, Quantitative, and Mixed Methods Approaches. 4th Edition, SAGE Publications, Thousand Oaks.

[36] Prgomet, M., Douglas, H.E., Tariq, A., Georgiou, A., Armour, P. and Westbrook, J.I. (2017) The Work of Front Line Community Aged Care Staff and the Impact of a Changing Policy Landscape and Consumer-Directed Care. The British Journal of Social Work, 47, 106-124. https://doi.org/10.1093/bjsw/bcw112

[37] Bulamu, N., Kaambwa, B., Gill, L., Cameron, I., McKechnie, S., Fiebig, J., Ratcliffe, J., et al. (2016) Impact of Consumer-Directed Care on Quality of Life in the Community Aged Care Sector. Geriatrics and Gerontology International, 17, 1399-1405. https://doi.org/10.1111/ggi.12872

[38] Gill, L., McCaffrey, N., Cameron, I.D., Ratcliffe, J., Kaambwa, B., Corlis, M., Gresham, M., et al. (2017) Consumer Directed Care in Australia: Early Perceptions and Experiences of Staff, Clients and Carers. Health and Social Care in the Community, 
25, 478-491. https://doi.org/10.1111/hsc.12328

[39] Laragy, C. and Allen, J. (2015) Community Aged Care Case Managers Transitioning to Consumer Directed Care: More than Procedural Change Required. Australian Social Work, 68, 212-227. https://doi.org/10.1080/0312407X.2014.991337

[40] You, E.C., Dunt, D. and Doyle, C. (2017) How Would Case Managers' Practice Change in a Consumer-Directed Care Environment in Australia? Health and Social Care in the Community, 25, 255-265. https://doi.org/10.1111/hsc.12303

[41] Eisenberg, M.D., Haviland, A.M., Mehrotra, A., Huckfeldt, P.J. and Sood, N. (2017) The Long-Term Effects of "Consumer-Directed" Health Plans on Preventive Care Use. Journal of Health Economics, 55, 61-75.

https://doi.org/10.1016/j.jhealeco.2017.06.008

[42] Stokoe, A., Hullick, C., Higgins, I., Hewitt, J., Armitage, D. and O'dea, I. (2016) Caring for Acutely Unwell Older Residents in Residential Aged-Care Facilities: Perspectives of Staff and General Practitioners. Australasian Journal on Ageing, 35, 127-132. https://doi.org/10.1111/ajag.12221

[43] Day, J., Taylor, A.C.T., Summons, P., Van Der Riet, P., Hunter, S., Maguire, J., Harris, M., et al. (2017) Home Care Packages: Insights into the Experiences of Older People Leading up to the Introduction of Consumer Directed Care in Australia. Australian Journal of Primary Health, 23, 162-169. https://doi.org/10.1071/PY16022

[44] Carmeli, A., Tishler, A. and Edmondson, A.C. (2012) CEO Relational Leadership and Strategic Decision Quality in Top Management Teams: The Role of Team Trust and Learning from Failure. Strategic Organization, 10, 31-54.

https://doi.org/10.1177/1476127011434797

[45] Elder, K., Aylen, T. and O’Keefe, F. (2016) Consumer Directed Care: A Client Experience. Australian Nursing and Midwifery Journal, 23, 48.

[46] Swaine, J.G., Parish, S.L., Igdalsky, L. and Powell, R.M. (2016) Consumers' and Workers' Perspectives about Consumer-Directed Services in the United States. Disability and Health Journal, 9, 464-471. https://doi.org/10.1016/j.dhjo.2016.01.002

[47] Pines, J.M., Mullins, P.M., Cooper, J.K., Feng, L.B. and Roth, K.E. (2013) National Trends in Emergency Department Use, Care Patterns, and Quality of Care of Older Adults in the United States. Journal of the American Geriatrics Society, 61, 12-17. https://doi.org/10.1111/igs.12072

[48] Shier, V., Khodyakov, D., Cohen, L.W., Zimmerman, S. and Saliba, D. (2014) What Does the Evidence Really Say about Culture Change in Nursing Homes? The Gerontologist, 54, S6-S16. https://doi.org/10.1093/geront/gnt147

[49] Singh, D.A. (2014) Effective Management of Long-Term Care Facilities. Jones and Bartlett Publishers, Burlington.

[50] Van Biljon, L. and Roos, V. (2015) The Nature of Quality of Life in Residential Care Facilities: The Case of White Older South Africans. Journal of Psychology in Africa, 25, 201-207. https://doi.org/10.1080/14330237.2015.1065054

[51] Chenoweth, L., Merlyn, T., Jeon, Y.H., Tait, F. and Duffield, C. (2014) Attracting and Retaining Qualified Nurses in Aged and Dementia Care: Outcomes from an Australian Study. Journal of Nursing Management, 22, 234-247.

https://doi.org/10.1111/jonm.12040

[52] Carayon, P., Wetterneck, T.B., Rivera-Rodriguez, A.J., Hundt, A.S., Hoonakker, P., Holden, R. and Gurses, A.P. (2014) Human Factors Systems Approach to Healthcare Quality and Patient Safety. Applied Ergonomics, 45, 14-25.

https://doi.org/10.1016/j.apergo.2013.04.023 
[53] Fetherstonhaugh, D., Tarzia, L., Bauer, M., Nay, R. and Beattie, E. (2016) “The Red Dress or the Blue?" How Do Staff Perceive That They Support Decision Making for People with Dementia Living in Residential Aged Care Facilities? Journal of Applied Gerontology, 35, 209-226. https://doi.org/10.1177/0733464814531089

[54] Al Saifi, S.A. (2015) Positioning Organizational Culture in Knowledge Management Research. Journal of Knowledge Management, 19, 164-189. https://doi.org/10.1108/JKM-07-2014-0287

[55] Williams, B., Perillo, S. and Brown, T. (2015) What Are the Factors of Organizational Culture in Health Care Settings That Act as Barriers to the Implementation of Evidence-Based Practice? A Scoping Review. Nurse Education Today, 35, e34-e41. https://doi.org/10.1016/j.nedt.2014.11.012

[56] West, M., Topakas, A. and Dawson, J.F. (2014) Climate and Culture for Health Care Performance. In: The Oxford Handbook of Organizational Climate and Culture, Oxford University Press, Oxford, 335-359.

[57] Alfes, K., Shantz, A.D., Truss, C. and Soane, E.C. (2013) The Link between Perceived Human Resource Management Practices, Engagement and Employee Behaviour: A Moderated Mediation Model. The International Journal of Human Resource Management, 24, 330-351. https://doi.org/10.1080/09585192.2012.679950

[58] Huang, Y., Lee, J., Mcfadden, A.C., Murphy, L.A., Robertson, M.M., Cheung, J.H. and Zohar, D. (2016) Beyond Safety Outcomes: An Investigation of the Impact of Safety Climate on Job Satisfaction, Employee Engagement and Turnover Using Social Exchange Theory as the Theoretical Framework. Applied Ergonomics, 55, 248-257. https://doi.org/10.1016/j.apergo.2015.10.007

[59] Bernoth, M., Dietsch, E., Burmeister, O.K. and Schwartz, M. (2014) Information Management in Aged Care: Cases of Confidentiality and Elder Abuse. Journal of Business Ethics, 122, 453-460. https://doi.org/10.1007/s10551-013-1770-7

[60] Yu, P., Zhang, Y., Gong, Y. and Zhang, J. (2013) Unintended Adverse Consequences of Introducing Electronic Health Records in Residential Aged Care Homes. International Journal of Medical Informatics, 82, 772-788. https://doi.org/10.1016/j.ijmedinf.2013.05.008

[61] Cicolini, G., Comparcini, D. and Simonetti, V. (2014) Workplace Empowerment and Nurses' Job Satisfaction: A Systematic Literature Review. Journal of Nursing Management, 22, 855-871. https://doi.org/10.1111/jonm.12028

[62] Kaasalainen, S., Brazil, K. and Kelley, M.L. (2014) Building Capacity in Palliative Care for Personal Support Workers in Long-Term Care through Experiential Learning. International Journal of Older People Nursing, 9, 151-158. https://doi.org/10.1111/opn.12008

[63] Boersma, P., van Werth, J.C., Lakerveld, J. and Dröes, R.M. (2015) The Art of Successful Implementation of Psychosocial Interventions in Residential Dementia Care: A Systematic Review of the Literature Based on the RE-AIM Framework. International Psychogeriatrics, 27, 19-35. https://doi.org/10.1017/S1041610214001409

[64] Ottmann, G., Allen, J. and Feldman, P. (2013) A Systematic Narrative Review of Consumer-Directed Care for Older People: Implications for Model Development. Health and Social Care in the Community, 21, 563-581. https://doi.org/10.1111/hsc. 12025

[65] Cardona, B., Fine, M., Stebbing, A., Duncan, C., Samsa, P. and Eagar, K. (2017) Measuring Consumer Outcomes: Development and Testing of the Australian Community Care Outcomes Measure. Australasian Journal on Ageing, 36, 69-71. https://doi.org/10.1111/ajag.12377 
[66] Papastavrou, E., Acaroglu, R., Sendir, M., Berg, A., Efstathiou, G., Idvall, E., Suhonen, R., et al. (2015) The Relationship between Individualized Care and the Practice Environment: An International Study. International Journal of Nursing Studies, 52, 121-133. https://doi.org/10.1016/j.ijnurstu.2014.05.008

[67] Twigg, D. and McCullough, K. (2014) Nurse Retention: A Review of Strategies to Create and Enhance Positive Practice Environments in Clinical Settings. International Journal of Nursing Studies, 51, 85-92.

https://doi.org/10.1016/j.ijnurstu.2013.05.015

[68] Kitson, A., Marshall, A., Bassett, K. and Zeitz, K. (2013) What Are the Core Elements of Patient-Centred Care? A Narrative Review and Synthesis of the Literature from Health Policy, Medicine and Nursing. Journal of Advanced Nursing, 69, 4-15. https://doi.org/10.1111/j.1365-2648.2012.06064.x

[69] Roos, V. and Du Toit, F. (2014) Perceptions of Effective Relationships in an Institutional Care Setting for Older People. SA Journal of Industrial Psychology, 40, 1-9. https://doi.org/10.4102/sajip.v40i1.1139

[70] Brownie, S., Horstmanshof, L. and Garbutt, R. (2014) Factors that Impact Residents' Transition and Psychological Adjustment to Long-Term Aged Care: A Systematic Literature Review. International Journal of Nursing Studies, 51, 1654-1666. https://doi.org/10.1016/j.ijnurstu.2014.04.011

[71] Ouyang, Y.Q., Zhou, W.B. and Qu, H. (2015) The Impact of Psychological Empowerment and Organizational Commitment on Chinese Nurses' Job Satisfaction. Contemporary Nurse, 50, 80-91. https://doi.org/10.1080/10376178.2015.1010253

[72] Oliver, B., Gallo, K., Griffin, M.Q., White, M. and Fitzpatrick, J. (2014) Structural Empowerment of Clinical Nurse Managers. Journal of Nursing Administration, 44, 226-231. https://doi.org/10.1097/NNA.0000000000000059

[73] Australian College of Nursing (2015) Leadership White Paper. https://www.acn.edu.au/wp-content/uploads/2017/10/acn nurse leadership white paper reprint 2017 web.pdf

[74] Hurley, J. and Hutchinson, M. (2013) Setting a Course: A Critical Review of the Literature on Nurse Leadership in Australia. Contemporary Nurse, 43, 178-182. https://doi.org/10.5172/conu.2013.43.2.178

[75] Van Wart, M. (2013) Lessons from Leadership Theory and the Contemporary Challenges of Leaders. Public Administration Review, 73, 553-565. https://doi.org/10.1111/puar.12069

[76] Chu, C.H., Wodchis, W.P. and McGilton, K.S. (2014) Turnover of Regulated Nurses in Long-Term Care Facilities. Journal of Nursing Management, 22, 553-562. https://doi.org/10.1111/jonm.12031

[77] Joiner, K.A. and Lusch, R.F. (2016) Evolving to a New Service-Dominant Logic for Health Care. Innovation and Entrepreneurship in Health, 3, 25-33. https://doi.org/10.2147/IEH.S93473

[78] Low, L.F. and Fletcher, J. (2015) Models of Home Care Services for Persons with Dementia: A Narrative Review. International Psychogeriatrics, 27, 1593-1600. https://doi.org/10.1017/S1041610215000137

[79] Shield, R.E.R., Looze, J., Tyler, D., Lepore, M. and Miller, S.C. (2014) Why and How Do Nursing Homes Implement Culture Change Practices? Insights from Qualitative Interviews in a Mixed Methods Study. Journal of Applied Gerontology, 33, 737-763. https://doi.org/10.1177/0733464813491141

[80] Van der Voet, J. (2014) The Effectiveness and Specificity of Change Management in 
a Public Organization: Transformational Leadership and a Bureaucratic Organizational Structure. European Management Journal, 32, 373-382.

https://doi.org/10.1016/j.emj.2013.10.001

[81] McCormack, B., Roberts, T., Meyer, J., Morgan, D. and Boscart, V. (2012) Appreciating the "Person" in Long-Term Care. International Journal of Older People Nursing, 7, 284-294. https://doi.org/10.1111/j.1748-3743.2012.00342.x

[82] Hutchinson, M. and Hurley, J. (2013) Exploring Leadership Capability and Emotional Intelligence as Moderators of Workplace Bullying. Journal of Nursing Management, 21, 553-62. https://doi.org/10.1111/j.1365-2834.2012.01372.x

[83] Doody, O. and Doody, C.M. (2012) Transformational Leadership in Nursing Practice. British Journal of Nursing, 21, 1212-1218.

https://doi.org/10.12968/bjon.2012.21.20.1212

[84] Goetsch, D.L. and Davis, S.B. (2014) Quality Management for Organizational Excellence. Pearson, Upper Saddle River. 